\title{
The Correlation Between Low Body Mass Index (Underweight) With Bone Strength On Elderly Women
}

\author{
Shafira Dwi Resnasari ${ }^{1}$, Basuki Supartono², Luh EkaPurwani ${ }^{3}$ \\ ${ }^{1}$ Medical Study Programme, Faculty of Medicine, University of Pembangunan Nasional \\ Veteran Jakarta \\ ${ }^{2}$ Orthopedic Department, Faculty of Medicine, University of Pembangunan Nasional \\ Veteran Jakarta \\ ${ }^{3}$ Nutrition Department, Faculty of Medicine, University of Pembangunan Nasional Veteran \\ Jakarta \\ J1. RS Fatmawati, Pondok Labu, South Jakarta 12450, Phone. (021) 7656971 \\ Email : shafirarsn@gmail.com
}

Receive : Dec 11th2019. Revised : Feb 1th2020. Published: Jun 27th2020

DOI: https://doi.org/10.22219/sm.Vol16.SMUMM1.10598

Background : Osteoporosis is a degenerative disease that often happend at women in elderly age with low body mass index. Standard examination for osteoporosis is bone density examination also known as Bone Mineral Density (BMD). This tool can interpret the patient's bone strength

Objective : This research aims to identify the correlation between low body mass index (underweight) with bone strength on elderly women.

Method : This is an observational analytic research which used cross sectional design. The sample consist of 65 respondents. The data were analyzed by using Chi-square test.

Result : The result shows a large group of respondents aged 60-65 years old with a percentage of $18.5 \%$ suffers from osteopenia and a percentage of $47.7 \%$ suffers from osteoporosis. Furthermore, a percentage of $13.8 \%$ in underweight respondents suffers from osteopenia and a percentage of $47.7 \%$ suffers from osteoporosis.

Conclusion : This research proves that there is a correlation between low body mass index with bone strength on elderly women with $\mathrm{P}$-value amounting to $0.022(\mathrm{P}<0.05)$ for variable correlationbetween elderly age with bone strength and $\mathrm{P}$-value of $0.002(\mathrm{P}<0.05)$ for variable correlationbetween low body mass index with bone strength.

Keyword : Osteoporosis, Body Mass Index, Bone Density

Copyright (C) 2020, First Author et al This is an open access article under the CC-BY-SA license

\section{INTRODUCTION}

Osteoporosis is a condition marked by the decrease of bone mass along with the disruption of the bone microarchitecture tissue that caused the bone to break easily and increase the risk of someone to experience a bone fracture (WHO). According to the International Osteoporosis Foundation (IOF), 1 out of 4 women in Indonesia from the age of 50-80 years old have higher risk to develope osteoporosis. 
One of the risk factors of osteoporosis is the low Body Mass Index (BMI). BMI is related to the bone mass, therefore someone with a low BMI, have the bone's mass peak of being low and a high risk to having osteoporosis.

Apart from BMI, there are other factors that affect the risk of osteoporosis occurance, one of them is an age factor. Along with increasing age, someone will have a risk of osteoporosis caused by the physiological functions of body organs that progressively decrease, thus the opportunities for the bone mass to decrease will increase more. Along with increasing age, osteoblasts cells will die faster caused by overactivity of the osteoclasts cells, so the bone cells can not be replaced and the bone mass will continue to decrease (Cosman, 2009 and Tjandra, 2009). According to the Indonesian Health Ministry in 2015, at the age of 75-85 years, women have two times higher risk than men to experience trabecular bone loss due to the aging process, a decrease in the process of calcium absorption and an increase in parathyroid hormone function. According to WHO in 2003, one of the gold standards for diagnosis of osteoporosis, i.e. through BMD examination to find out someone's bone density. The inspection has various kind of tools and methods, such as: Dual Energy X-ray Densitometry Absorptiometry (DXA), Densitometry Ultrasound and Computed Tomography (CT). In this research, researcher used ultrasound densitometry tool, because the tool is available where the research is carried out, also the procedure can be done quickly, safely, easy and not risky.

\section{METHODS}

\section{Research Design}

This research used an observational analytic research design which aims to find out the correlation between variables through testing hypothesis. This research used the cross-sectional approach, which namely data has taken and processed at the same time to analyze the correlation of independent variables and dependent variables (Swarjana 2016, p.54).

\section{Population and Sample}

The population in this research are women with the age of 60 years old or older at AlFauzan Hospital. The samples in this research are all the subjects that fulfill the inclusive and exclusive criteria.

Inclusion criteria in this research are women, age 60 years old or older with low BMI and are at Al-Fauzan Hospital. There are also exclusive criteria in this research, which are the history of distuption on hepar function, history of having a disruption of kidney function, history of bone infection, history of Diabetes Mellitus (DM), history of Thyroid sickness (Hypertiroid), and history of using steroid drugs for some period of time.

\section{Sampling}

Collecting sample of this research used simple random sampling method, which taking sample members from the population randomly without noticing the strata that exists in the population (Sugiyono, 2017). 


\section{Data}

The data used in this study are primary data taken from questionnaires, measuring body weight and height, also measuring the Bone Mineral Density (BMD) to know the bone density in order to determine the strength of the respondent's bone. The questionnaire used in this study containing osteoporosis risk factors according to the International Osteoporosis Foundation (IOF) which contained 20 questions.

\section{Research Procedure}

Respondents were 65 people. Researcher collaborated with Al-Fauzan General Hospital to collect the respondents. Then, the researcher distributed questionnaires followed by measured the weight and height of each study participant and measure bone density using a Bone Mineral Density (BMD) Portable tool to determine bone strength. The researcher recorded all of the results of the examination that met the characteristics of the study, including name, age, gender, address, cell phone number, weight, height and the results of the questionnaire that had been distributed and filled out by all study participants.

\section{RESULTS}

\section{Respondent Characteristics}

Characteristics of respondents based on the elderly most are estimated to be 60-65 years with a total of $43(66.2 \%)$ respondents. Based on body mass index, most of them are underweight with a total of $40(61.5 \%)$ respondents. Based on bone strength, most of it is bone strength with the results of BMD osteoporosis with a total of $41(63.1 \%)$ respondents. The distribution of respondent characteristics can be seen in Table 1 .

Table 1. Distribution of The Respondent Characteristics

\begin{tabular}{lcc}
\hline & Frequency (n) & Percentage (\%) \\
\hline Age & 43 & $66.2 \%$ \\
$60-65$ years & 3 & $4.6 \%$ \\
$66-70$ years & 19 & $29.2 \%$ \\
$71-75$ years & & \\
\hline Body Mass Index & 25 & $38.5 \%$ \\
Normoweight & 40 & $61.5 \%$ \\
Underweight & & $36.9 \%$ \\
\hline Bone Strength & 24 & $63.1 \%$ \\
Osteopenia & 41 & \\
Osteoporosis & & \\
\hline
\end{tabular}




\section{The correlation between elderly women with bone strength}

Bivariate analysis in this study was performed using the Chi-square test. The results of bivariate analysis of elderly women with bonestrength obtained $p$ value of 0.022 ( $p<0.05)$ which means there is a correlation between the age of the elderly with bone strength. The $\mathrm{p}$ value can be seen in Table 2.

Table 2. The Correlation Between Elderly Women With Bone Strength

\begin{tabular}{ccccccccc}
\hline & \multicolumn{9}{c}{ Bone Strength } & & \multirow{2}{*}{ Total } & \multirow{2}{*}{ P-Value } \\
\cline { 2 - 5 } & \multicolumn{2}{c}{ Osteopenia } & \multicolumn{2}{c}{ Osteoporosis } & & & \\
\hline Age & $\mathrm{N}$ & $\%$ & $\mathrm{~N}$ & $\%$ & $\mathrm{~N}$ & $\%$ & \\
\hline $60-65$ years & 12 & 18.5 & 31 & 47.7 & 43 & 66.2 & \\
$66-70$ years & 3 & 4.6 & 0 & 0 & 3 & 4.6 & \multirow{2}{*}{0.022} \\
$71-75$ years & 9 & 13.8 & 10 & 15.4 & 19 & 29.2 & \\
\hline Total & 24 & 36.9 & 41 & 63.1 & 65 & 100 & \\
\hline
\end{tabular}

The correlation between low body mass index (underweight) with bone strength

Bivariate analysis in this study was performed using the Chi-square test. The results of bivariate analysis of low body mass index with bone strength obtained p value of 0.002 ( $p<0.05$ ) which means there is a correlation between low body mass index (underweight) with bone strength. The $\mathrm{p}$ value can be seen in Table 3 .

Table 3. The Correlation Between Low Body Mass Index With Bone Strength.

\begin{tabular}{ccccccccc}
\hline & \multicolumn{9}{c}{ Bone Strength } & & \multirow{2}{*}{ Total } & \multirow{2}{*}{ P-Value } \\
\cline { 2 - 5 } & \multicolumn{2}{c}{ Osteopenia } & \multicolumn{2}{c}{ Osteoporosis } & & & \\
\hline Age & $\mathrm{N}$ & $\%$ & $\mathrm{~N}$ & $\%$ & $\mathrm{~N}$ & $\%$ & \\
\hline $60-65$ years & 15 & 23.1 & 10 & 15.4 & 25 & 38.5 & \\
$66-70$ years & 9 & 13.8 & 31 & 47.7 & 40 & 61.5 & \multirow{2}{*}{0.002} \\
\hline Total & 24 & 36.9 & 41 & 63.1 & 65 & 100 & \\
\hline
\end{tabular}

\section{DISCUSSION}

Based on the research result, it is obtained that respondent with the age of 60-65 years old are the most to experience an osteoporosis with the proportion of $47.7 \%$. Aside from it, the respondent with a low body mass index obtained a proportion of $47.7 \%$ experienced osteoporosis. Base of the analysis result of a bivariate test with Chi-square, it is obtained a P-Value of 0.022 $(p<0.05)$ for correlation between variables of elderly age with bone strength, also P-Value of 0.002 
$(\mathrm{p}<0.05)$ for correlation between the variable of low body mass index with bone strength. With that can be concluded that there is a correlation between low body mass index (underweight) with bone strength on elderly women. Low body mass index and elderly age cause the decrease in someone's bone density. Whereas in someone with a low body mass index tend to have a low peak of bone mass, thus risking them to osteoporosis. Aside from it, an elderly women that have experienced menopause, there will be a decrease in estrogen hormone, causing the decrease of osteoblast activities and the increase of osteoclast activities (Health Department, 2015). The opportunity of osteoporosis is two times bigger at the age of $75-85$ years old, caused by trabecular bone loss due to the aging process, a decrease in the process of calcium absorption and an increase in parathyroid hormone function. This research result is in line with Ong, Terence et al 2004, which stated that underweight increased the risk of osteoporosis and fracture from happening $(\mathrm{p}=<0.001)$.

\section{SUMMARY}

This research proves that there is a correlation between low body mass index with bone strength on elderly women with P-value amounting to $0.022(\mathrm{P}<0.05)$ for variable correlation between elderly age with bone strength and $\mathrm{P}$-value of $0.002(\mathrm{P}<0.05)$ for variable correlation between low body mass index with bone strength.

\section{SUGGESTION}

For elderly women with the age of $\geq 60$ years old with a low body mass index $(<18.5)$, it is expected to look after their body mass index so it could reach the normal limit of body mass index by fulfilling the nutrition need and exercise to decrease the risk of having a low number of bone strength that could be rated by the result of an early BMD as an early screening to the possibility of having osteoporosis.

For the next research, it is expected to be able to do a research from the result of BMD measurement in elderly women with a low body mass index that has been doing a control routine for 1 year.

\section{ACKNOWLEDGMENTS}

Gratitude for Allah SWT presence of the writer, for all of the miracle that made this research, "The CorrelationBetween Low Body Mass Index (Underweight) with BoneStrength on Elderly Women", possible and ended well. The writer expressed much gratitude to Dr. dr. Basuki Supartono, SpOT, FICS, MARS as the best Supervisor that had helped in the process of finishing this research, also on giving helpful suggestions and motivation, and also, to related parties, the Director of RSU Al-Fauzan dr. Prita Kusumaningsih, SpOG, along with staffs that were involved, for their availability to be the research location and allowance to borrow the tools to support this research. 
Also, much gratitude the writer expressed to many parties that had given their support, especially mother - Rizma Reni, father - Odang Supriatna, beloved Grandmother - Rosina Muin, also siblings - Sylvia Resnasari, Tirana Mutiara Dewi, and Muhammad Fachri Alfathir, that had given their never-ending love and support toward Writer. Especially for their prayers for Writer's success.

\section{REFERENCES}

And Management of Osteoporosis : Report of A WHO Scientific Group, Geneva. http://www.who.int/iris/bitstream/10665/42841/1/WHO_TRS 921.pdf

Bijelic, R, et al 2017. Risk Factors for Osteoporosis In Postemenopausal Women, Med Arch. pp 2528.

Book a Guide for Patient and Their Families. Oxford University Press. New York.

Cooper, C. \&Ferrari, S 2017. IOF Compendium of Osteoporosis. Journal of International Osteoporosis Foundation.

Cosman, F. 2009. Osteoporosis: Panduan Lengkap agar Tulang Anda Tetap Sehat. Bintang Pustaka. Jakarta.

Ganong, WF 2008. Buku Ajar Fisiologi Kedokteran. EGC. Jakarta

http://journals.lww.com/thoracicimagin/Fulltext/2013/09000/QuantitativeComputed Tomograp

hy_of_Diffuse_Lung.2.aspx

http://www.depkes.go.id/download.php?file=download/pusdatin/infodatin/infodatin-

osteoporosis.pdf

http://www.iofbonehealth.org/sites/default/files/PDFs/Audit\%20Asia/Asiansregional_audit_200 9.pdf

International Osteoporosis Foundation 2009. The Asian Audit Epidemiology, Cost and Burdn of Osteoporosis in Asia 2009.

Kementerian Kesehatan RI 2010. Juknis SIRS. Sistem Informasi Rumah Sakit. Lane 2001. The Osteoporosis

Kementerian Kesehatan RI 2015.Data dan Kondisi Penyakit Osteoporosis di Indonesia. Infodatin Pusat Data Dan Informasi Kementrian Kesehatan RI. pp. 1-8. Retrieved from

Kementerian Kesehatan RI 2017. Analisis Lansia di Indonesia. Infodatin Pusat Data Dan Informasi Kementrian Kesehatan RI.

Limawan, D.Mewo,YM.Kaligis,SH, 2015. Gambaran Kadar Kalsium Serum Pada usia 60-70 Tahun. Jurnal e-Biomedik.

Lynch, DA 2013. Quantitative Computed Tomography of Diffuse Lung Disease. Journal of Thoracic Imaging. Vol. 28. Issue. 5. pp. 264-265.

Morin, S, et all 2009. Weight And Body Mass Index Predict Bone Mineral Density and Fractures in Woman Aged 40 to 59 Years. Journal of Osteoporosis International. Vol. 20. pp 363-370. 
Mow, Van C \& Huiskes, Rik, 2005. Basic Orthopaedic Biomechanic and Mechanobiologi Third Edition. Lippincott Williams and Wilkins. USA

National Osteoporosis Foundation, 2015. Exercise for Strong Bones. Washington.

Ong, Terence, et al 2014. A United Kingdom Perspective On The Relatioship Between Body Mass Index (BMI) and Bone Health. Journal of Bone. Vol. 59. pp 207-210.

Putri, Alissa, 2009. Tetap Sehat di Usia Lanjut. Genus Printika. Yogyakarta

Ramadani, M 2010. Faktor-Faktor Resiko Osteoporosis Dan Upaya Pencegahannya. Jurnal Kesehatan Masyarakat Andalas. hlm 111-115

Setiyohadi, B 2006. Osteoporosis dalam Buku Ilmu Penyakit Dalam Jilid II. Edisi IV. Jakarta: Pusat Penerbitan Departemen Ilmu Penyakit Dalam Fakultas Kedokteran Universitas Indonesia.

Sherwood, L 2011. Human Physiology: fromCells to System.EGC. Jakarta

Sugiyono 2017. Metode Penelitian Kuantitatif,Kualitatif dan R \& D. Alfabeta. Bandung.

Swarjana 2016. Statistik Kesehatan. Penerbit Andi. Yogyakarta.

Wardlaw, Gordon M 1996. Putting Body Weight and Osteoporosis Into Perspective. Journal of American Journal of Clinical Nutrion. Vol. 63.

Waseso, L.B., Supartono, B. \& Fauziah, 2017. Physical Activity ang The Strength of Bone in Menopause Patients in National Sports Hospital in 2017. Jumal Berkala Kedokteran. 14(1). pp. 69-74

World Health Organization 2003. Prevention

Zhao, Lan Juan, et al 2017. Relatioship Between Body Mass Index and Osteoporosis. Journal of Medicinski Pregled Medical Review. Vol. 69. Issue. 1. pp 85-88. diakses tanggal 19 Juli 2019. 